\title{
Fruit and seed production in a natural population of a dioecious plant: Piliostigma reticulatum HOSCHT (Caesalpinioïdeae)
}

\author{
Madjélia Cangrè Ebou DAO ${ }^{1}$, Boukary Ousmane DIALLO ${ }^{2 *}$ and \\ Chantal KABORE-ZOUNGRANA ${ }^{3}$
}

\author{
${ }^{1}$ Département Productions Forestières/Institut de l'Environnement et de Recherches Agricoles/ \\ Centre National de la Recherche Scientifique et Technologique 03 BP 7047 Ouagadougou Burkina Faso. \\ ${ }^{2}$ Département Productions Forestières/Institut de l'Environnement et de Recherches Agricoles/ \\ Centre National de la Recherche Scientifique et Technologique 03 BP 7047 Ouagadougou Burkina Faso. \\ ${ }^{3}$ Université Polytechnique de Bobo-Dioulasso 01 BP 1091 Bobo Dioulasso 01, E-mail : cykabore@yahoo.fr \\ *Corresponding author, E-mail: ousboukdiallo@yahoo.fr
}

\begin{abstract}
Plant fruit/seed production is a central subject of many questions in plant evolutionary and conservation biology. In the Sudano-Sahelian forest of Burkina Faso, fruit and seed production of a common dioecious shrub, Piliostigma reticulatum, were assessed by considering plant size, fruiting success and distance between male and female individuals. The results showed that $P$. reticulatum has a low production of fruits and seeds (17.63 $\mathrm{g} \pm 3.33 \mathrm{SE}$ of fruit per plant and $0.1045 \mathrm{~g} \pm 0.0018 \mathrm{SE}$ per seed). A large percentage of the seeds aborted (40\%) and were damaged by herbivory (10\%). The fruiting success ranged from 0.1 to 0.4 . The percentage of seeds attacked by insects was negatively correlated with the mean diameter of the canopy and the height of trees. When the female of $P$. reticulatum was more than 10 meters from the male, fruit and seed productions were greater. The conclusion was that losses of flowers and fruits were important and suggested further information on pollination limitation or genetic studies to identify the cause of the insufficient quality and quantity of fruit and seed productions of $P$. reticulatum.
\end{abstract}

() 2012 International Formulae Group. All rights reserved.

Keywords: Piliostigma reticulatum, dioecious, fruiting success, soudanian forest, Burkina Faso.

\section{INTRODUCTION}

Piliostigma reticulatum (Caesalpinioideae) is a dioecious forage species widely recognized in the soudanian and sahelian areas of West Africa. Its pods are collected almost entirely from natural populations and the processing is done locally. During the last 10 years, however, large scale collection has frequently occurred in northern soudanian zone of Burkina Faso where commercial harvest and marketing represent a major income source for rural and suburban collectors and processors (CIFOR and CNRST, 2006). Therefore the household income shortfall across this entire supply chain was frequently attributed to insufficient pod production. The socio-economic link between pod production and income can also have clear consequences for sustainable management of the natural population of $P$. 
reticulatum. A comprehensive synthesis of factors explaining fruit production of $D$. reticulatum is lacking. Indeed, there is a paucity of quantitative information on fruit production of most tropical non-timber forest product (fruits, nuts, and seeds) of commercial interest. This is surprising given that nontimber forest products are considered as important component of the economy in developing countries as well as tropical forest conservation strategies (Lescuyer, 2010). Moreover, the status of dioecy confers additional vulnerability in the sahelian area. Since dioecious plant species are largely pollinated by insects rather than through wind pollination (Bawa, 1990), fruiting success in such species largely depends on the sex ratio of the population (Carlsson- Graner et al., 1998; Osunkoya, 1999), and behaviour of pollinators (House, 1992; Stacy et al., 1996). In addition to this, human practises in the open dry tropical forest such as excessive cutting of branches and trees to feed goats, sheep and cattle (personal observations) may also limit the fruit and seed production. The potential effect of the spatial distribution of the sexes within the population of the dioecious species is of particular importance for the fruiting. Fruit set can be limited also by the size of the plant and by fruit and seed predation. Plant size had a consistent positive effect on flowering amplitude in both sexes in a dioecious plant but its effects on other factors, including the extent of fruit set, varied (Torimaru and Tomaru, 2006). Fruit and seed are often eaten by larvae of predators in the soudanian zone (Dao et al., 2006). Many studies have been done in tropical rain forest on the sex ratio, reproductive success and spatial patterns of dioecious plants (Mack, 1997; Ollerton and Lack, 1998; Torimaru and Tomaru, 2006) but it has not received much attention in the dry tropical regions. Therefore, the main objective of this study was to estimate fruit and seed production of trees and to investigate the consequences of the distance between male and female trees on fruit and seed production of $P$. reticulatum in tropical dry forests, a dioecious plant with different types of plant visitors (Dao et al., submitted). The main focus was to address the following questions: (1) what is the average fruit and seed productivity of Piliostigma tree? (2) Do fruit and seed production vary in response to distance between the male and female individuals? (3) What factors explain production, focusing on the tree size (diameter of the canopy and height)? (4) What is the effect of predation on fruit and seed production? (5) Is loss of fruits and seeds to predators related to the plant size?

\section{MATERIALS AND METHODS}

\section{Study species}

$P$. reticulatum is a perennial dioecious tree or shrub about 8-10 m of height, growing from the northern part of the soudanian zone to the sahelian zone of Burkina Faso (Arbonnier, 2009). Both females and males produce flowers which are white with pink stripes. Inflorescences are axillaries or terminal panicles and range from $5-15 \mathrm{~cm}$ long. Flowering begins in July and the fruiting in late September which corresponds with the rainy season (Dao et al., 2010). Flowers attract many insect visitors and Apidae (Hymenoptera) has been identified as the most abundant and frequent potential pollinators (Dao et al., submitted). Flower buds and flowers are often eaten by larvae of predators. Fruits pods develop during the growing season, ripen in December-January and remain on the plant even after the next year's flowering. Relatively few pods are produced because they are damaged by predators and have few viable seeds.

\section{Study site}

The study was conducted at Budtenga village located $40 \mathrm{~km}$ east of Ouagadougou, Burkina Faso (Figure 1). Budtenga is located in the north soudanian zone, and the 
vegetation is a shrub savannah. Soils are ferruginous tropical loamy soils (Guinko and Fontès, 1995). Rainfall is unimodal: the rainy season lasts from May to September and the average monthly rainfall during the last three years shows an increase in rainfall (in 2007 particularly in August and September).

\section{Vegetal material}

The study was conducted in a natural population of $P$. reticulatum at Budtenga where we expected to sample a large number of male and female plants with flowers. All the plants with flowers were marked and Sex expression was determined on the abscised flowers. The study population was characterized by female individuals that produced fruits (female trees) and by fruitless male individuals.

\section{Plants sampling and data collection}

Distance between male and female individuals and fruit production

To determine the favourable distance for successful fruit production all the female plants have been selected and the distance between each female and the nearby male measured. A total of 19 circles with $20 \mathrm{~m}$ radius were sampled. Twenty meters are used based on the main pollinator's behaviour of $P$. reticulatum (Apis mellifera) (Diallo, 2001). The circle was centered around a female plant. During the period of fruit maturity (December 2008) fruit and seed were collected from all female plant in each circle and then the dry mass was estimated.

\section{Fruiting success}

Twenty one female plants, 10 racemes per plant and 10 flower buds per raceme were selected at random at the beginning of flowering period (July 2007). During the period of fruit maturity, the number of racemes with mature fruits was counted. Fruits were determined to be ripe from their colour had changed from green to brown. The proportion of flowers that developed into mature fruits was used as an estimate of fruiting success after open pollination in the population.

Impact of the plant size on fruit and seed production

To evaluate fruit and seed production, 25 female plants were selected at random in the population at the beginning of flowering time (July 2007). We measured the following growth parameters of the plants: height (m) and diameter of the canopy (m). During the period of fruit maturity, all mature fruits from each plant were collected. The damaged (pods that were perforated by parasites or aborted) and undamaged pods were collected separately for each plant. Fruit length and dry mass were recorded. Fruits were oven-dried at $70{ }^{\circ} \mathrm{C}$ for one day. The average weight of fruit coat and seeds were estimated and the percentage of damaged fruits and seeds calculated.

\section{Data analysis}

Fruiting success was calculated as the ratio the number of mature fruits in a raceme to the number of flower bud in the raceme [mature fruits/flower buds per raceme]. Minitab 13 was used to perform a simple regression analysis to examine the relationship between the responses variables (fruit and seed dry mass, seed attacked and seed abortion) and the predictor variables (distance to nearest male, plant height and canopy diameter).

\section{RESULTS}

Impact of distance between female and male plants on fruit and seed production

The Figure 2 shows that the percentage of undamaged seed was positively related to the distance to the nearest male (Pearson's correlation coefficient $\mathrm{r}=0.55, \mathrm{P}<0.05 ; \mathrm{n}=$ 19 females). Keeping in mind that the radius of the circles was $20 \mathrm{~m}$, the nearest flowering male was within a distance of $5 \mathrm{~m}$ in 52 percent of flowering females (Figure 3a) and 
the maximum distance to the nearest flowering male was $15 \mathrm{~m}$ from any flowering female. Fruit and seed production differed according to distant between male and female plants (Figure 3b). For distances less than 5 $\mathrm{m}$, females produced less fruit (2631 g) and seed (6 $446 \mathrm{~g}$ ) than the others. For distances greater than $10 \mathrm{~m}$, females produced more seed (8 $286 \mathrm{~g}$ ).

\section{Fruiting success}

Fruiting success ranged from 0 to $40 \%$ (Figure 4). The greatest success was recorded among a small percentage of trees (10\%) and $38 \%$ of sampled trees completely lost their fruit before maturity.

\section{Fruit and seed production}

$P$. reticulatum produced $17.63 \mathrm{~g} \pm 3.33$ SE of fruit coat per plant and $0.1045 \mathrm{~g} \pm$ $0.0018 \mathrm{SE}$ per seed in the study population. Fruit length was estimated at $16.35 \mathrm{~cm} \pm 0.45$ SE. Figure 5 shows the percentage of seed attacked $(10.49 \%)$, seed aborted $(39.98 \%)$ and undamaged seed $(49.57 \%)$ per plant. There was an effect of height on fruit and seed production (Table 1). The production of fruit per class ranged from 16.91 to $18.26 \mathrm{~g}$. The lowest height class $(2-3 \mathrm{~m})$ produced the lowest average weight of mature fruit (16.91 g) and the highest height class $(4-5 \mathrm{~m})$ produced the highest average weight of mature fruit $(18.26 \mathrm{~g})$. The production of seed per height class was also different and ranged from $45.29 \mathrm{~g}$ to $41.59 \mathrm{~g}$. But the lowest height class produced more seed $(45.29 \mathrm{~g})$ than the other classes. A decrease in percent of seed attacked was observed from the smallest to the highest height class (Table 1). This means that $13.57 \%$ of seeds produced by individuals in the 2-3 m height class were attacked, but only $8.48 \%$ were attacked in the highest height class. The same tendency was observed when we considered the average number of holes made by the predator on fruit. The percentage of abortion of seeds varied according to the height of the plants. The middle height class of height (3-4 m) aborted $42.61 \%$ of their seeds whereas the lowest class aborted only $33.62 \%$. Figures $6 \mathrm{a}$ and $6 \mathrm{~b}$ show that fruit production was unrelated to the size of the female trees (Pearson's correlation coefficient $r=0.39 ; \mathrm{P}>0.05$ for canopy diameter and Pearson's correlation coefficient $r=0.09$; $\mathrm{P}>0.05$ for the height). But there was a significant positive relationship between fruit production and the mean number of holes on the fruit (Figure 6c) (Pearson's correlation coefficient $\mathrm{r}=0.47 ; \mathrm{P}<0.05)$. The regression analysis showed that the strongest relationship was with the variable "seed attacked" (Figure 7). The variable "seed attacked" was negatively correlated with the mean diameter of the canopy (Figure 7a) and the height of the female trees (Figure 7b). Their Pearson's correlation coefficients were respectively $\mathrm{r}=$ 0.45 and 0.52 and their P-values were less than 0.05 . Whereas in the Figure $7 \mathrm{c}$, seed abortion was unrelated to the height of the female trees (Pearson's correlation coefficient $\mathrm{r}=0.09 ; \mathrm{P}>0.05)$.

Table 1: Fruit and seed production according to the size of trees.

\begin{tabular}{lcccccc}
\hline $\begin{array}{l}\text { height } \\
(\mathbf{m})\end{array}$ & $\begin{array}{c}\text { Number of } \\
\text { individuals }\end{array}$ & $\begin{array}{c}\text { Average } \\
\text { weight of } \\
\text { fruit coat }(\mathbf{g})\end{array}$ & $\begin{array}{c}\text { Average } \\
\text { number of } \\
\text { holes/fruit }\end{array}$ & $\begin{array}{c}\text { Average } \\
\text { weight of } \\
\text { seed }(\mathbf{g})\end{array}$ & $\begin{array}{c}\text { Seeds } \\
\text { aborted } \\
(\boldsymbol{\%})\end{array}$ & $\begin{array}{c}\text { Seeds } \\
\text { attacked by } \\
\text { parasites }(\boldsymbol{\%})\end{array}$ \\
\hline $2-3$ & 5 & 16,91 & 2,98 & 45,29 & 33,62 & 13,57 \\
$3-4$ & 18 & 17,76 & 2,59 & 37,55 & 42,61 & 9,71 \\
$4-5$ & 2 & 18,26 & 2,24 & 41,59 & 36,01 & 8,48 \\
\hline
\end{tabular}




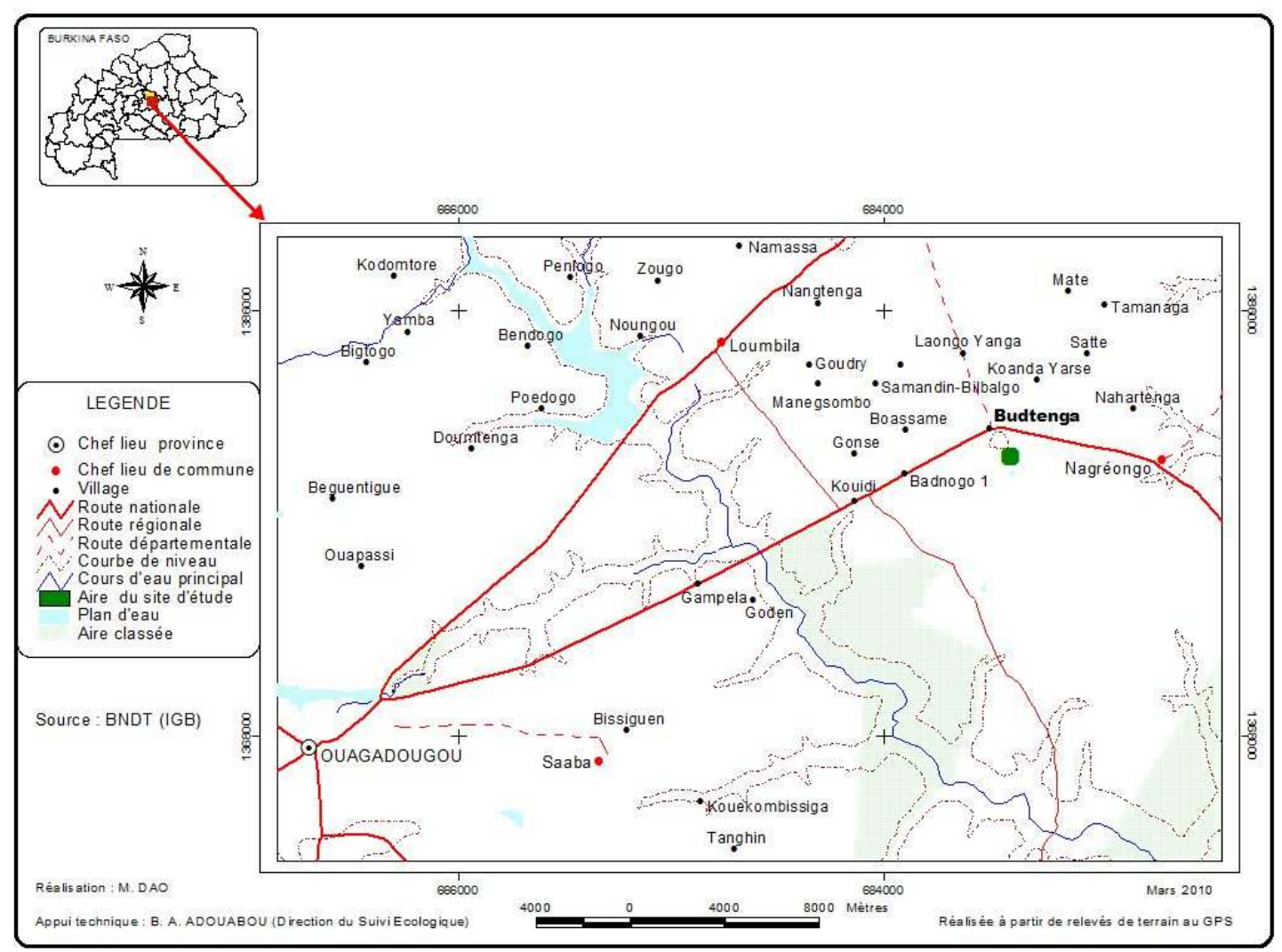

Figure 1: Location of the study area.

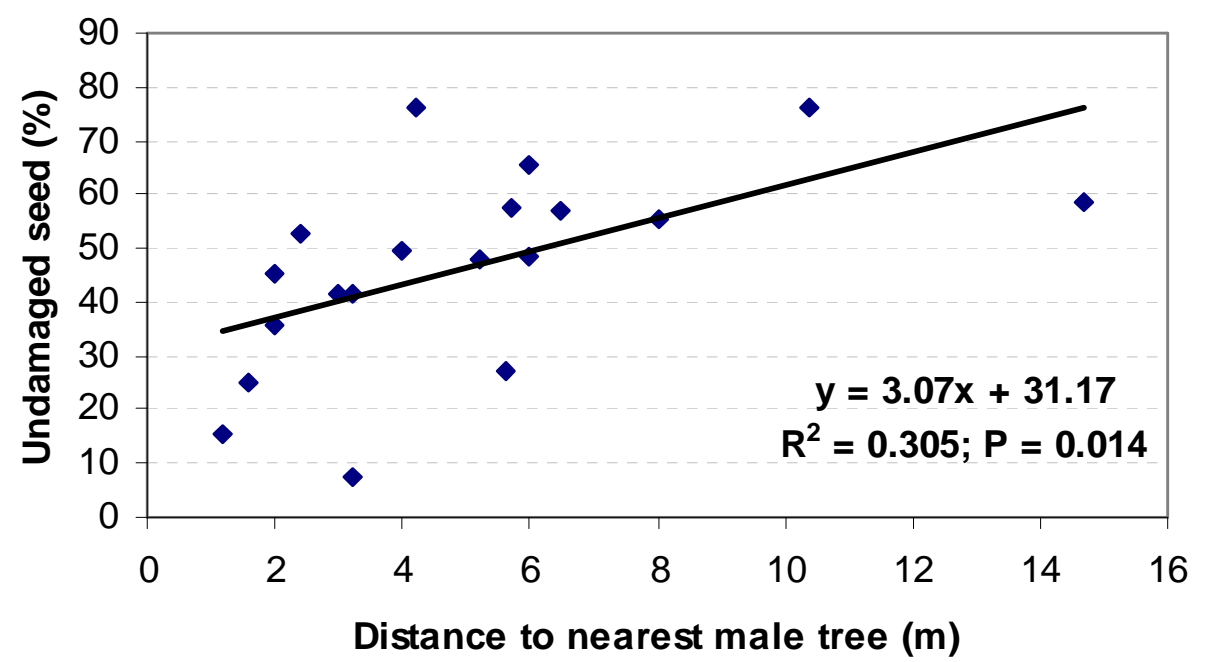

Figure 2: The relationship between the percentages of seed undamaged produced by female trees and the distance to the nearest male trees in P. Reticulatum. 

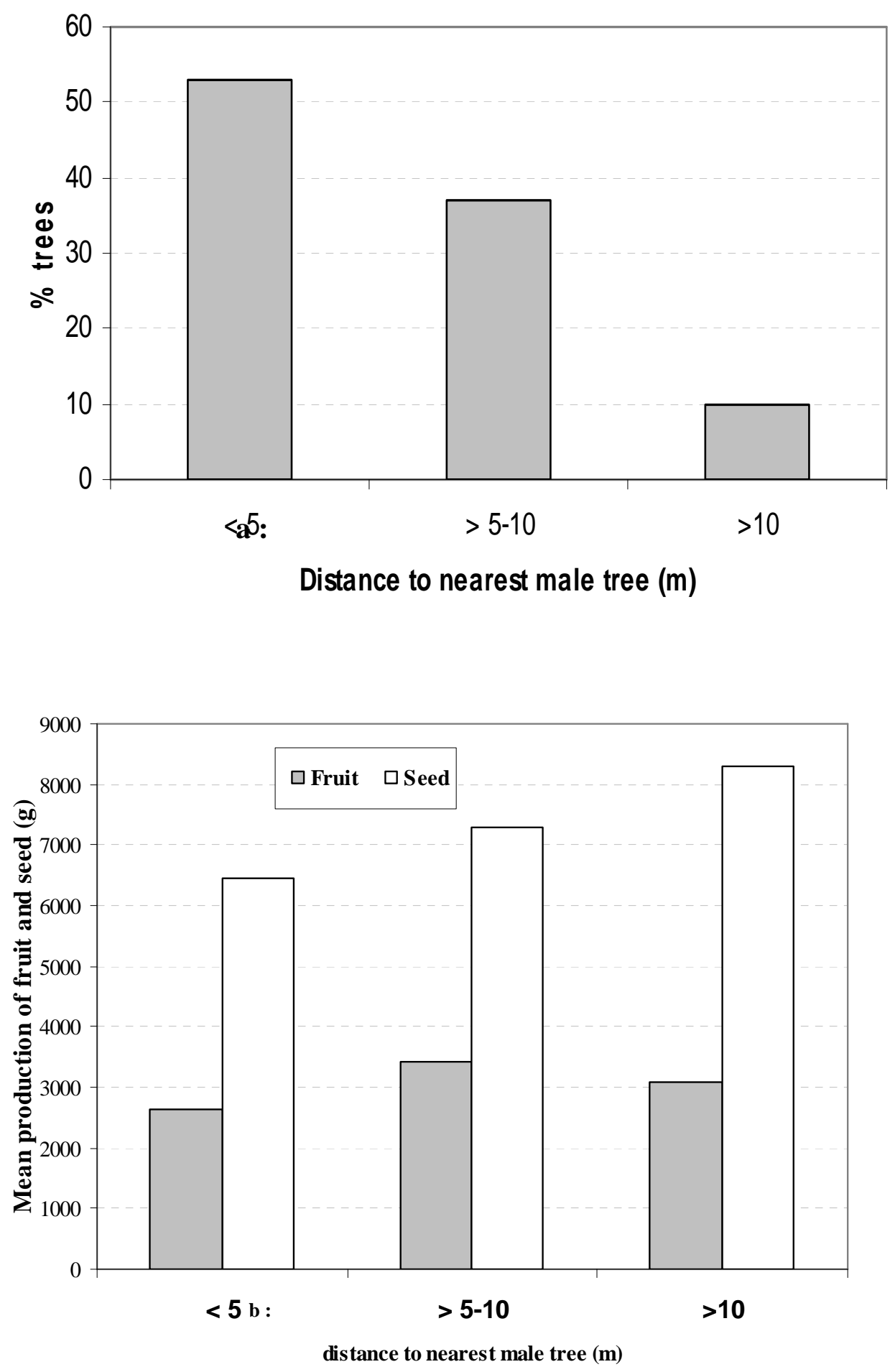

Figure 3: Frequency distribution of the distance from female trees to the nearest mal trees (a) and fruit and seed production in P. reticulatum (b). 


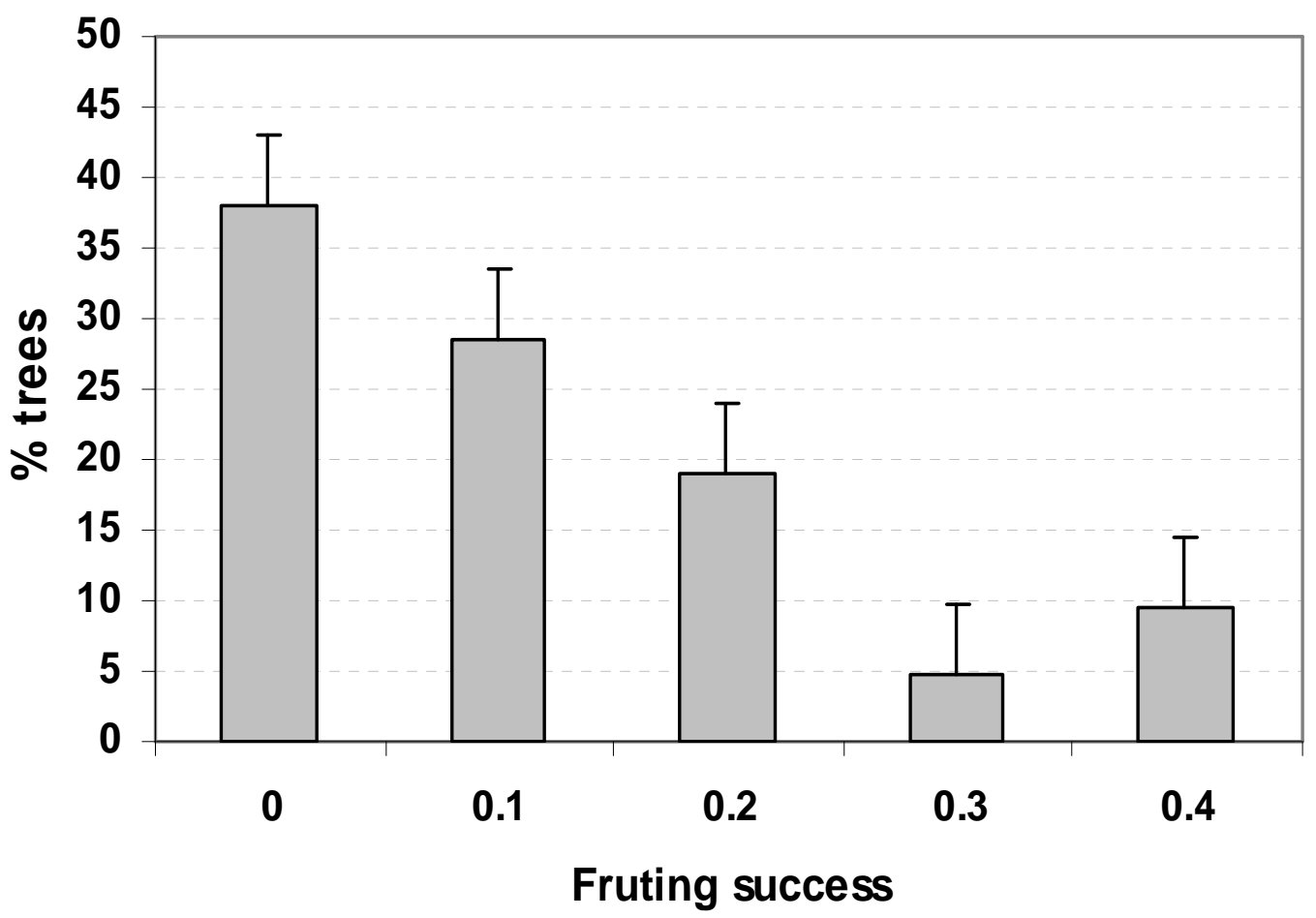

Figure 4: Different fruiting successes and their percentages of trees.

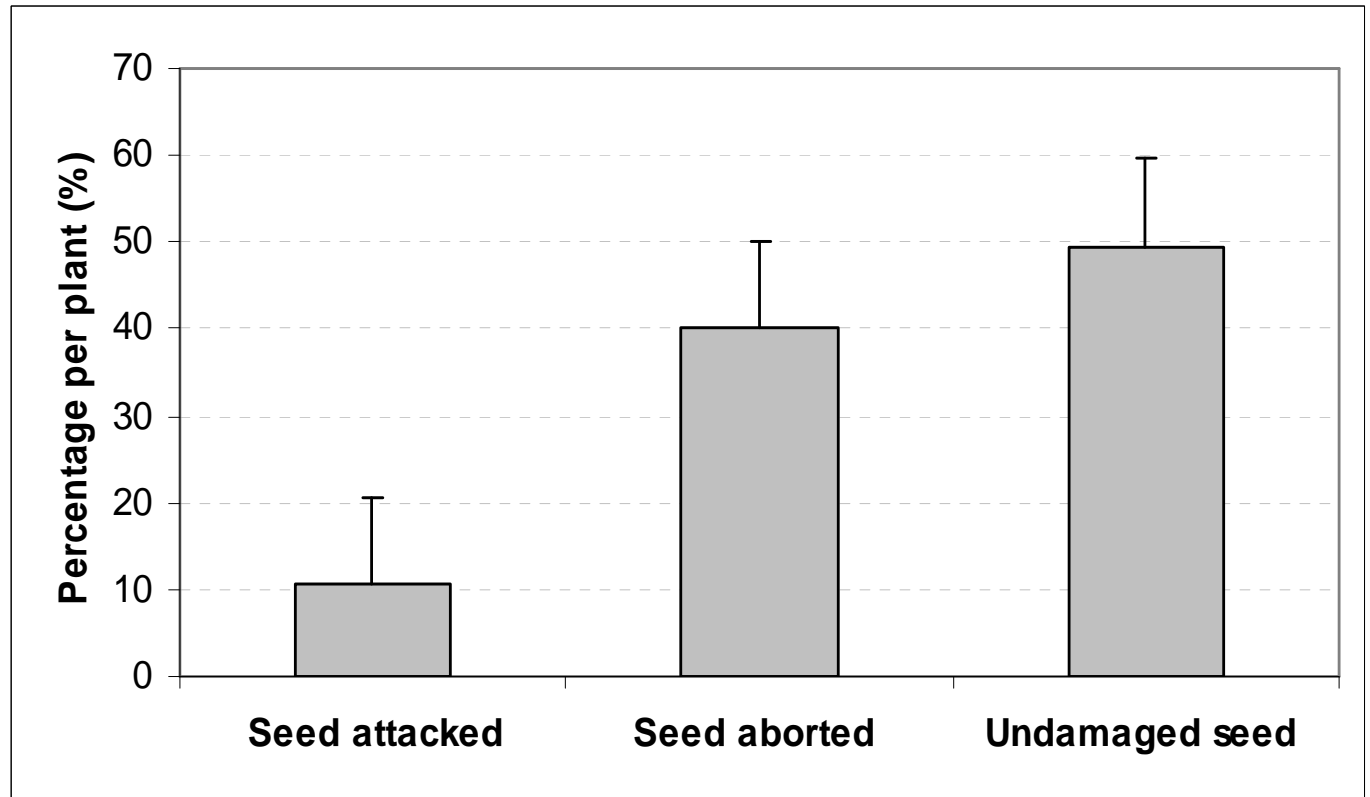

Figure 5: Percentage of seeds attacked, aborted and undamaged per plant. 

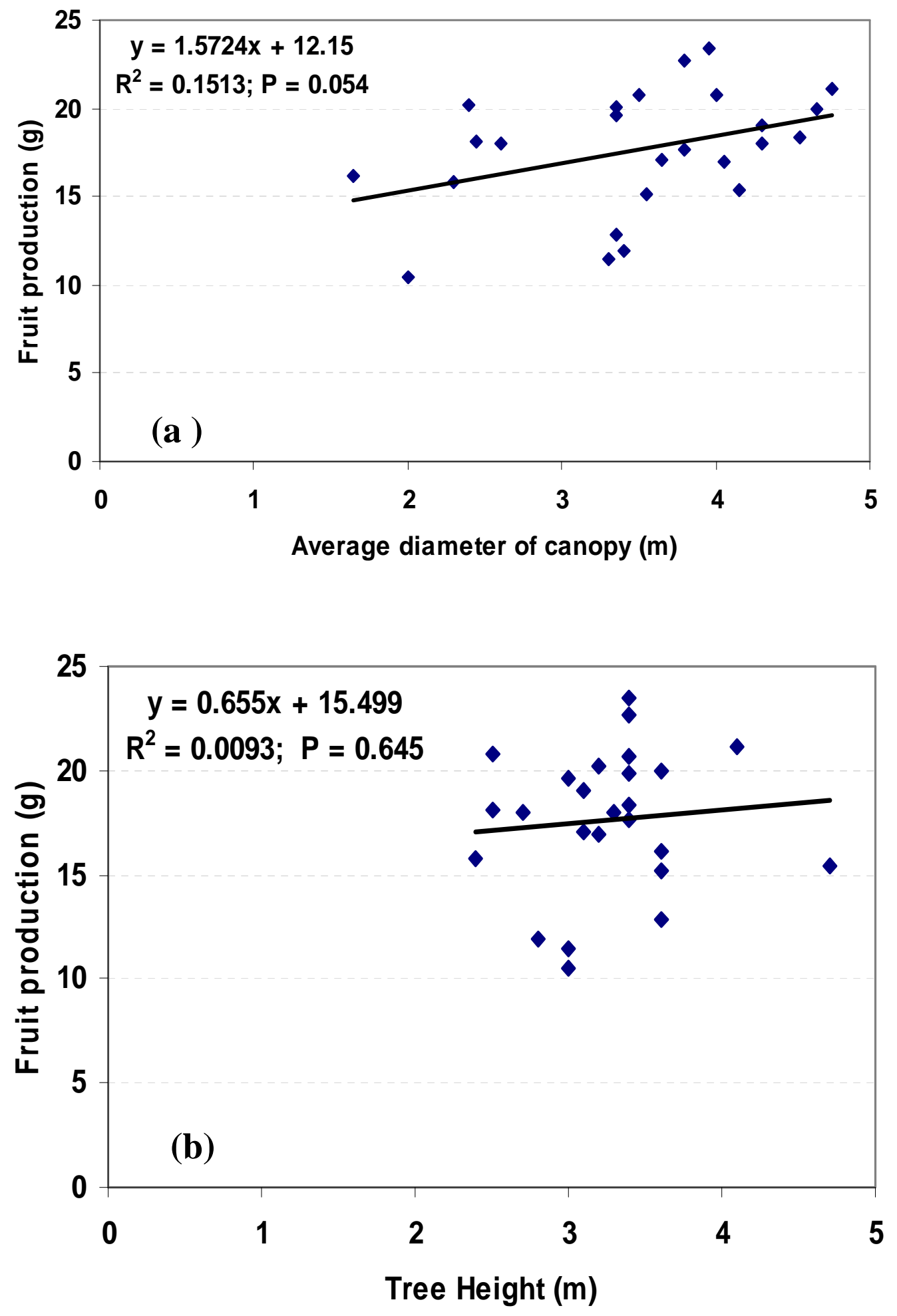


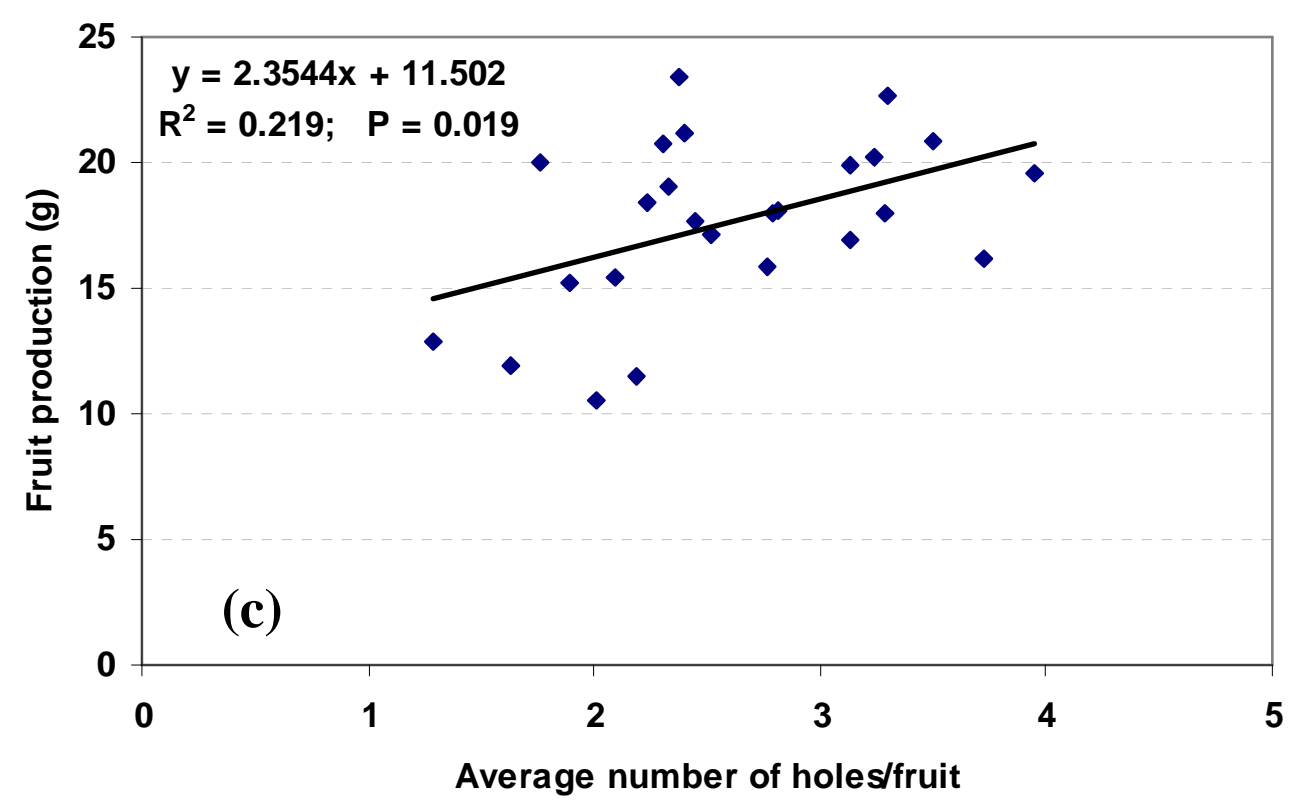

Figure 6: The relationship between the weight of fruit produced and (a) the average diameter of canopy of the female trees; (b) the height of tree (c) the average number of holes per fruit $(n=25)$.

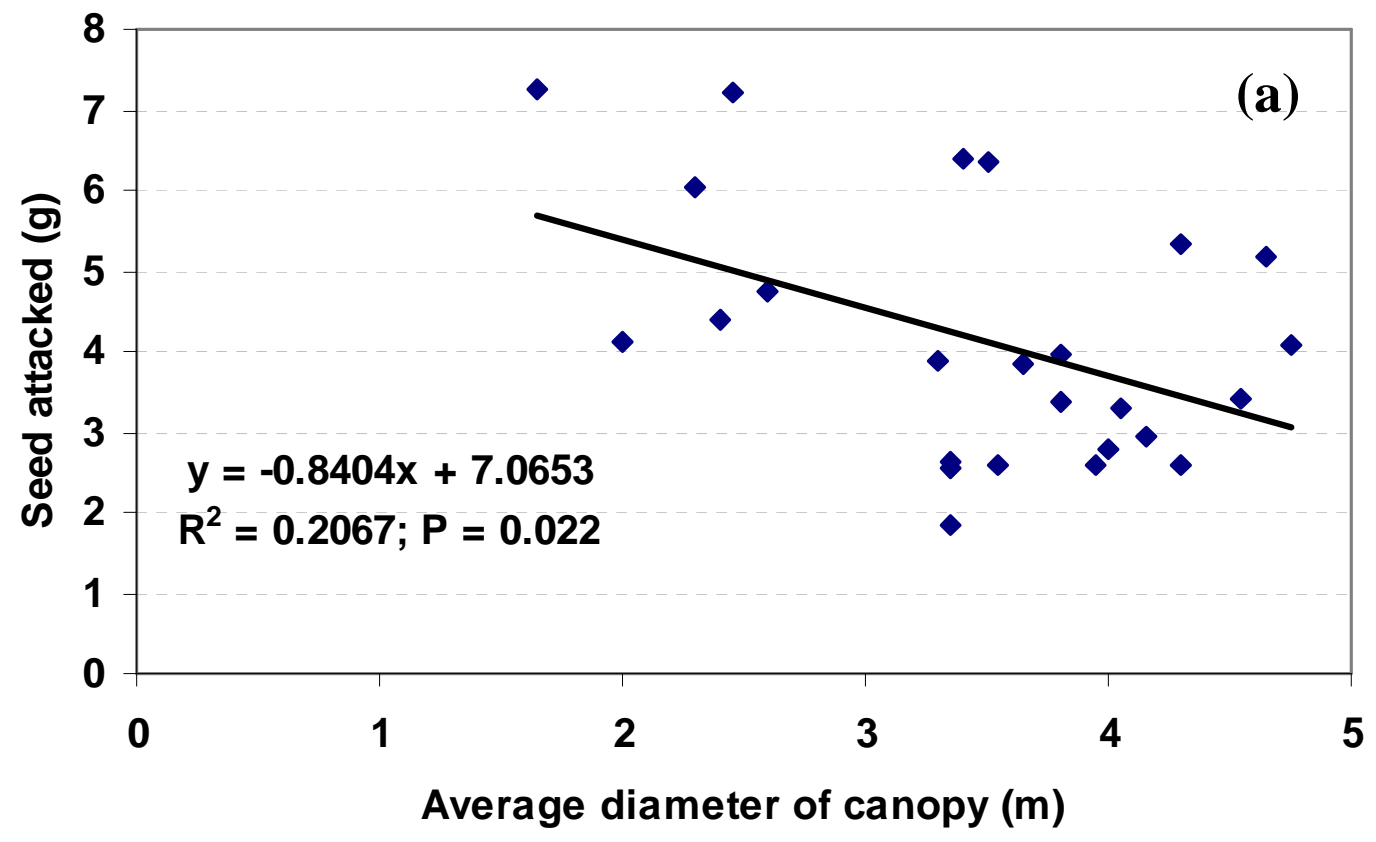



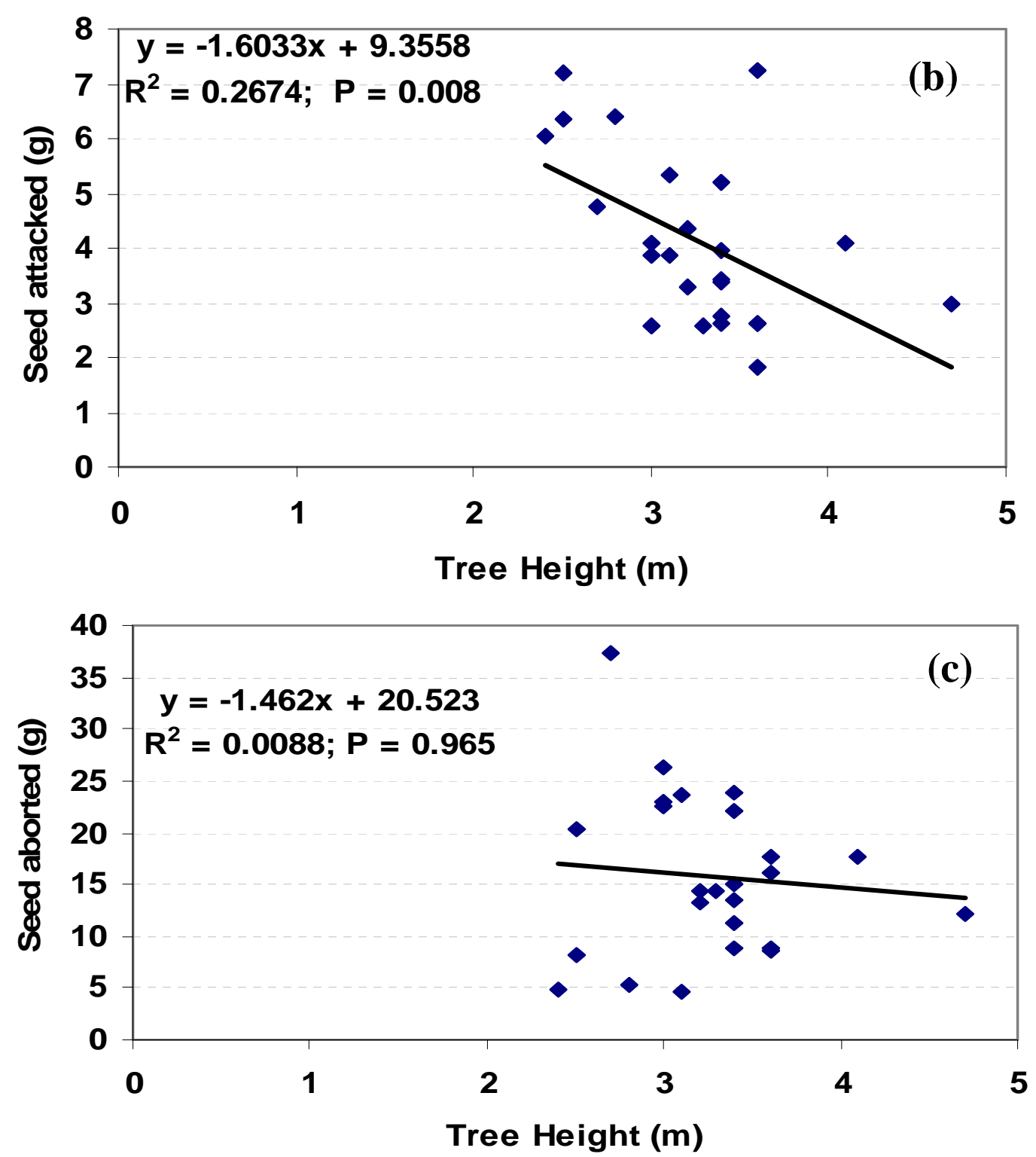

Figure 7: The relationship between the weight of seed attacked in P. reticulatum and (a) the diameter of canopy of the female trees; (b) the height of tree; (c) the relationship between the weight of seeds aborted and the height of tree $(n=25)$.

\section{DISCUSSION}

We found that fruit and seed production differed according to distant between male and female individuals. Below $5 \mathrm{~m}$, the average production of female plants were $2631 \mathrm{~g}$ of fruits and $6446 \mathrm{~g}$ of seeds. Above $10 \mathrm{~m}$, the female individuals produced greater mass of seed $(8286 \mathrm{~g})$. When male and female were less distant, this produced an aggregate of abundant flowers which were expected to display an important number of flowers and to enhance the attractiveness to a variety of insects where predators were commonly observed at any time during the flowering season and regardless of weather conditions (Dao et al., submitted). Predator species often aggregate to areas of high resource abundance (Ushimaru et al., 2007). 
When the insect predators were abundant on the tree, they caused severe limitation of fruit and seed set or their total failure (Rathcke, 2001). The results showed that the fruiting success in $P$. reticulatum was low. Plants fruits/flowers was low. Only a few racemes bore a few mature fruits. During the reproductive period, losses of flowers and fruits were quite high as also reported in other leguminous trees (Diallo et al., 2008). In dioecious species, many factors can explain why not all flowers develop into mature fruits. For example, predation due to herbivory may have caused reduction in fruit and seed production or alternatively, quality of pollen transfer in a dioecious species has caused low fruit production (Sutherland and Delph, 1984).

The estimated yield per tree was an average of $17.63 \mathrm{~g} \pm 3.33 \mathrm{SE}$ of fruit coat per plant and $0.1045 \mathrm{~g} \pm 0.0018 \mathrm{SE}$ per seed. The low yield of Piliostigma confirms what is known in most of the Sudanian and Sahelian legume tree species such as Tamarindus indica (Diallo et al., 2008). This may be due to climatic conditions. Moreover, we recorded per plant $40 \%$ of aborted seeds and $10 \%$ of parasitized seeds. This finding is in line with previous studies on the major African insect pests Caryedon serratus which feed on the seeds of some native host plants like Bauhinia rufescens, Piliostigma reticulatum, Piliostigma thonningii, Tamarindus indica, which all belong to the Leguminous subfamily Caesalpinioideae (Delobel et al., 2003). The high percentage of aborted seeds may reflect selfincompatibility which is important in the breeding systems of many tropical species (Sage et al., 1994). Self-incompatibility is related to the quality of pollen transferred on the stigma. Honeybees (Apis mellifera) have been identified as the dominant floral visitors to flowers of $P$. reticulatum and potential pollinators of the species. They frequently groom pollen from their body, storing it in the corbiculae making it inaccessible for transfer onto the stigmatic surface (Bernhardt and Weston, 1996; Paton, 1997; Wallace et al., 2002). Combined with the high proportion of movements within plants (Gross, 2001; Dupont et al., 2004) and restricted movements between plants (Michaelson-Yeates et al., 1997), this would encourage selfing and biparental inbreeding, respectively. Therefore, honeybees may be inefficient as pollinators of $P$. reticulatum, which is an outcrossing species. Honeybees co-visited $P$. reticulatum's flowers with a range of other insect families including Ichneumonidae, Vespidae, Muscidae, Syrphidae, Lycidae, Meloidea Scarabaeidae Acraeidae and Nymphalidae, Acrididae and Coreidae (Dao et al., submitted). This composition of floral visitors has been shown to have a direct negative effect on reproductive success (Spira, 2001), to alter the genetic structure of populations (England et al., 2001) and to encourage (bi-parental) inbreeding depression (Spira, 2001). Other causes of flower, fruit, and seed abortion have been described by Bawa and Webb (1984) for several tropical trees. In that study, the position of the fruits within the inflorescence and seed within the ovary affected abortion. Their results indicated that some fruits abort because of competition for resources, and flowers that open first have a higher probability of retention than those set by flowers that open later. Older fruits may interfere with resource allocation to younger fruits. Therefore, all these factors, as well as self-incompatibility, may contribute to fruit and seed loss in P. reticulatum.

A relationship between tree size and fruit and seed production was observed. Plants with low percentage of seed attacks tended to be taller and larger. Although plant height and canopy diameter were significantly and negatively correlated with attacked seed, they were not significantly correlated with other parameters of fruit and seed production. Thus, even if they are simple non-destructive measures, they could not be considered as good predicators of plant production after one year estimation. 


\section{Conclusion}

The present study revealed that $P$. reticulatum bloom profusely but fruit and seed production are low. There are many flower and fruit losses during the reproductive period. It appears that distance between male and female individuals in the population influences tree productivity. The quality of fruit and seed produced are severely reduced by predation. These results emphasize that a consideration of plantanimal interactions, including pollinators and predators and their unique responses, may be necessary to understand the insufficient production of fruit and seed of $P$. reticulatum

\section{ACKNOWLEDGMENTS}

We thank the ICRAF/IFAD project (IFAD technical assistance grant 799) for guidance about methodological approach; A. Bonkoungou and M. Zagré for their contributions to collect data in the field; the people from Budtenga who provided logistical and personal support; and I. Ouedraogo and John Webber for their useful comments and advice on English.

\section{REFERENCES}

Arbonnier M. 2009. Arbres, Arbustes et Lianes des Zones Sèches d'Afrique de l'Ouest, (3 ${ }^{\text {ème }}$ édn Revue et augmentée). MNHN-QUAE; $576 \mathrm{p}$.

Bawa KS. 1990. Plant pollinator interactions in tropical rain forests. Annual Review of Ecology and Systematics, 21: 399-422.

Bawa KS, Webb JC. 1984. Flower, fruit and seed abortion in tropical forest trees: Implications for the evolution of paternal and maternal reproductive patterns. American Journal of Botany, 71: 736751.

Bernhardt P, Weston PH. 1996. The pollination ecology of Persoonia (Proteaceae) in eastern Australia. Telopea, 6: 775-804.

Carlsson-Graner U, Elmqvist TAÊ, Gren J, Gardfjell H, Ingvars-son P. 1998. Floral sex ratios, disease and seed set in dioecious Silene dioica. Journal of Ecology, 86: 79-91

CIFOR, CNRST. 2006. Les gousses de Piliostigma sp., Documentaire CIFORCNRST Ouagadougou, Burkina Faso.

Dao M, Diallo BO, Tamini Z, Bastide B, Guinko S. 2006. Evolution de la morphologie florale chez Ziziphus mauritiana Lam. (Rhamnacae) : mouvements des pièces florales et des étamines. Cameroon Journal of Experimental Biology, 2(2): 70-76.

Dao MCE, Diallo OB, Kaboré-Zoungrana C. 2010. Hermaphrodisme morphologique et diœcie physiologique dans une population de Piliostigma reticulatum (DC) HOSCHT (Caesalpinioideae). Cameroun Journal of Experimental Biology, 6(1): 21-30.

Delobel A, Sembène M, Fédière G, Roguet D. 2003. Identity of the groundnut and tamarind seed-beetles (Coleoptera: Bruchidae Pachymerinae), with the restoration of Caryedon gonagra (F.). Ann. Soc. Entomol. Fr., 39(3): 197-206

Diallo BO. 2001. Biologie de la reproduction et évaluation de la diversité génétique chez une légumineuse: Tamarindus indica L. (Caesalpinioïdae), thèse de Doctorat, Université Montpellier II, Sciences et Technique du Langue doc, 119 p. + annexes.

Diallo BO, McKey D, Chevallier M-H, Joly HI, Hossaert-McKey M. 2008. Breeding system and pollination biology of the semi domesticated fruit tree, Tamarindus indica L. (Leguminosae: Caesalpinioideae): Implications for fruit production, selective breeding and conservation of genetic resources. African Journal of Biotechnology, 7(22): 4068-4075.

Dupont YL, Hansen DM, Alfredo V, Oleson JM. 2004. Impact of introduced honey bees on native pollination interactions of the endemic Echium wildpretii (Boraginaceae) on Tenerife, Canary Islands. Biological Conservation, 118: 301-311. 
England PR, Beynon F, Ayre DJ, Whelan RJ. 2001. A molecular genetic assessment of mating-system variation in a naturally bird-pollinated shrub: contributions from birds and introduced honeybees. Biological Conservation, 15: 1645-1655.

Gross CL. 2001. The effect of introduced honeybees on native bee visitation and fruit-set in Dillwynia juniperina (Fabaceae) in a fragmented ecosystem. Biological Conservation, 102: 89-95.

Guinko S, Fontès J. 1995. Notice explicative de la carte de la végétation et de l'occupation du sol du Burkina Faso. Proj. «Campus», Min. Coop. Fr., Univ. Ouagadougou, Burkina Faso, 66p.

House SM. 1992. Population density and fruit set in three dioecious tree species in Australian tropical rain forest. Journal of Ecology, 80: 57-69.

Lescuyer G. 2010. Importance économique des produits forestiers non ligneux dans quelques villages du Sud Cameroun. BFT, 64(304): 15-24.

Mack AL. 1997. Spatial distribution, fruit production and seed removal of a rare, dioecious canopy tree species (Aglaia aff. flavida merr. Et Perr.) in Papua New Guinea. Journal of Tropical Ecology, 13: $305-316$.

Michaelson-Yeates TPT, Marshall AH, Williams IH, Carreck NL, Simpkins JR. 1997. The use of isoenzyme markers to determine pollen flow and seed paternity mediated by Apis mellifera and Bombus spp. in Trifolium repens, a selfincompatible plant species. Journal of Apicultural Research, 36: 57-62.

Ollerton J, Lack A. 1998. Relationships between flowering phenology, plant size and reproductive success in Lotus corniculatus (Fabaceae). Plant Ecology, 139: 35-47.

Osunkoya OO. 1999. Population structure and breeding biology in relation to conservation in the dioecious Gardenia actinocarpa (Rubiaceae) a rare shrub of North Queensland rainforest. Biological Conservation, 88: 346-359.
Paton DC. 1997. Honey bees Apis mellifera and the disruption of plant-pollinator systems in Australia. Victorian Naturalist, 114: 3-29.

Rathcke BJ. 2001. Pollination and Predation Limit Fruit Set in a Shrub, Bourreria succulenta (Boraginaceae), after Hurricanes on San Salvador Island, Bahamas. Biotropica, 33(2): 330-338.

Sage TL, Bertin RI, Williams EG. 1994. Ovarian and Other Late-Acting SelfIncompatibility Systems. Kluwer Academic, Dordrecht: The Netherlands.

Spira TP. 2001. Plant-pollinator interactions: a threatened mutualism with implications for the ecology and management of rare plants. Natural Areas Journal, 21: 78-88.

Stacy EA, Hamrick JL, Nason JD, Hubbell SP, Foster RB, Condit R. 1996. Pollen dispersal in low density populations of three neotropical tree species. American Naturalist, 148: 275-298.

Sutherland S, Delph LF. 1984. On the importance of male fitness in plants: patterns of fruit set. Ecology, 65(4): 1093-1104.

Torimaru T, Tomaru N. 2006. Relationships between flowering phenology, plant size, and female reproductive output in a dioecious shrub, Ilex leucoclada (Aquifoliaceae). Canadian Journal of Botany, 84(12): 1860-1869.

Ushimaru A, Watanabe T, Nakata K. 2007. Colored floral organs influence pollinator behavior and pollen transfer in commelina communis (Commelinaceae). American Journal of Botany, 94(2): 249-258.

Wallace HM, Maynard GV, Trueman SJ. 2002. Insect flower visitors, foraging behaviour and their effectiveness as pollinators of Persoonia virgata $\mathrm{R}$. Br. (Proteaceae). Australian Journal of Entomology, 41: 55-59. 